\title{
Effects of Chemical Fertilizer, Algea Compost and Zeolite on Green Bean Yield
}

$\begin{array}{ll}\text { Aysun Türkmen }{ }^{*}, \text { Yalçın Kütük } & \\ \text { Department of Chemistry, Faculty of Science And Art, Giresun University, 28000 Giresun, Turkey }\end{array}$

\section{Introduction}

The lands to be used as agricultural areas are almost extinct on all over the world. Depending on the increased number of population there is now more need of food production to feed this population. Therefore, it is needed to obtain more crops per area and as a result of this there is a dramatic increase in the use of chemical components. As a consequence of this intense use of crop yield and production amount has increased; however, sustainable soil fertility and natural balance have been affected negatively. Consequently, mostly in the economically powerful countries, producers and consumers in many countries have founded organizations and started to prefer agricultural products which are non-toxic to humans and produced with methods which do no harm to environment.

Brown seaweed of Cystoseira type is one of these and they generally grow on rocky shores. It is more common in warm, clean and oxygenated seas. Also it is an important trade iodine resource (Çakı, 2009; Altuner, 2010). When the sea algae products stay for a long time under the soil, they decompose easily under natural circumstances and create ample amount of nitrogen $(\mathrm{N})$ and calcium $(\mathrm{Ca})$. Moreover, it involves magnesium $(\mathrm{Mg})$, manganese $(\mathrm{Mn})$, boron $(\mathrm{B})$, iron $(\mathrm{Fe})$, zinc $(\mathrm{Zn})$, copper $(\mathrm{Cu})$ and cobalt $(\mathrm{Co})$. Marine brown seaweed has high capacities of combining and accumulating metals in the environment so it is a good indicator (Davis et al., 2003; Ostapczuk et al., 1997; Krishnani and Ayyappan, 2006). Today, it is known that, marine seaweed is used in agriculture and especially in biological agriculture in many parts of the world to increase fertility and durability, improve soil structure and feed cattle.

In this study, brown algae are buried after being composted. Because compost used in reclamation of the lands used in cultivation has positive effects on plant growth directly and indirectly. For example, it has been observed that the application of compost to the soil results in the increase in quality and fertility of the land and also it helps the development of the plant roots (Güvenç and Y1ldırım, 1999). Having the characteristics of humus, composts are obtained by the mineralization due to the microbial decomposition of garbage, animal wastes, tailings like hay or straw, kitchen residues, municipal wastes and organic factory wastes after various operations. These are organic fertilizers that are free of pathogens and smells and looks like heather humus, as they were subjected to aerobic decomposition. 
Zeolite as an organic fertilizer was used in this study. In agriculture, only the clinoptilolite type of zeolite $\left[\left(\mathrm{Na}_{3} \cdot \mathrm{K}_{3}\right)\left(\mathrm{Al}_{6} \mathrm{Si}_{30} \mathrm{O}_{72}\right) \cdot 24 \mathrm{H}_{2} \mathrm{O}\right]$ is used. Preventing the washing of $\mathrm{NH}_{4}^{+}$used as a fertilizer, clinoptilolite ensures that $\mathrm{NH}_{4}^{+}$is kept in the soil. Zeolite being in crystal structure, containing alkaline earth cations is an easy and abundant silicate. It is characterized by its nature of losing and gaining water and its cation exchange without a major change in its structure (Altan et al., 1998).

When we classify the green bean $(P$. vulgaris) used as a plant material, we can say the following information about it: Ordo: Fabales, Family: Fabaceae, Genus: Phaseolus, Species: P.vulgaris. There are pilous, green compound leaves at its gnarling stem. Butterfly flowers clustering at the axils are white, pink or purple. Green beans are rich with vitamins $\mathrm{A}, \mathrm{B} 1, \mathrm{~B} 2$, and $\mathrm{C}$. Green beans has also base excess which can neutralize the acid accumulated in human body. Digestibility ratio of green bean is \%84.1. Phasol and phaseolin which are found in green bean pods are reported to be holding the same features as insulin that is used to cure diabetes thus these substances are put into use in order to lower the amount of sugar in blood. Cultivation of beans is getting more and more important recent days when the applications of sustainable agriculture and environmentalism are becoming widespread because of its positive features such as nitrogen deposition and correction of the soil structure (Ülker and Ceyhan 2008).

Because of the ignorant and excessive use of the chemical fertilizers and continuously growing the same kind of plant species, the natural structure of the soil is deteriorating; serious problems for agriculture such as soil fatigue arises. The use of organic fertilizer will have an important role in overcoming these problems which result in decrease in quality and fertility. After the applying the compost state of brown seaweed (Cystoseria sp.), zeolite, and chemical fertilizer at the same concentrations but with various combinations to the soil and observing the effects on green bean plant (P.vulgaris), this study will reveal the most efficient combination for the plant.

\section{Materials and Method}

\section{Collecting Cystoseria sp.}

Algae (Cystoseira sp.) used in the experiment was collected from the surrounding areas of Hotel New Jasmin which is located in coastline of the Gemiler Çekeği district of Giresun at latitude $40^{\circ} 54^{\prime} 59.02^{\prime \prime} \mathrm{N}$ and longitude $38^{\circ} 25^{\prime} 09.13^{\prime \prime}$ E. Research was conducted using the pots in the area of Giresun Hazelnut Research Center applying Randomized Complete Block Design between May and November in 2014 with three replications.

\section{Preparation of Compost Organic Fertilizer}

Handpicked algae was washed with sea water and cleaned from epiphyte, sediment and other organic matter. The samples were carried in polyethylene bags to the laboratory, washed one more time with tap water to remove the salt and contamination, and then aged in fresh water in plastic containers for a day. Then the sample was left to dry (Sivasankari et al., 2006). After drying, the sample was left for fermentation for 25 days to be composted in fermenter under anaerobic condition. At the end of the fermentation the material was milled and analyzed in terms of plant nutrient elements.

\section{Zeolite Material}

In the experiments, zeolite clinoptilolite $\left[\left(\mathrm{Na}_{3} \cdot \mathrm{K}_{3}\right)\left(\mathrm{Al}_{6} \mathrm{Si}_{30} \mathrm{O}_{72}\right) \cdot 24 \mathrm{H}_{2} \mathrm{O}\right]$ type belonging to Manisa Gördes is used as ion exchanger. The dimensions of the materials vary between 5-15 $\mu \mathrm{m}$. Chemical composition of clinoptilolite were as follows; $\mathrm{SiO}_{2} ; 71.3, \mathrm{Al}_{2} \mathrm{O}_{3} ; 13.6$, $\mathrm{Fe}_{2} \mathrm{O}_{3} ; 1.15, \mathrm{~K}_{2} \mathrm{O} ; 3.50, \mathrm{CaO} ; 1.96, \mathrm{MgO} ; 0.70, \mathrm{Na}_{2} \mathrm{O}$; $0.60, \mathrm{Ag} ; 0.004$ and $\mathrm{Ti} ; 0.02$ as percentage, and $\mathrm{B} ; 30$ as ppm (Altan et al., 1998).

\section{Chemical Fertilizer}

Chemical fertilizer used in the experiment is NPK (2020-20) fertilizer which is widely employed in agriculture. Fertilizer groups were created in order that a total amount of $25 \mathrm{~kg}$ chemical fertilizer would be added to each pot.

\section{Seed Material}

The seeds of green bean ( $P$. vulgaris) were bought from a company that sells certified seeds. The seeds were kept in their special packets in an atmosphere of $5^{\circ} \mathrm{C}$ until the beginning of the experiment.

\section{Seeding Method}

Research was conducted using the pots in the area of Giresun Hazelnut Research Center applying Randomized Complete Block Design between May and November in 2014 with three replications. Seeding was done by hand in order that $20 \mathrm{seeds} / \mathrm{m}^{2}$ should be in depth of $5-6 \mathrm{~cm}$ on $30^{\text {th }}$ May, 2014. At the seedling stage, each pot was left with six saplings and other conditions were also equalized with this arrangement with the exception of fertilization.

\section{The Fertilization Method}

Apart from control group, other pots were given $50 \mathrm{~g}$ zeolite, $50 \mathrm{~g}$ compost and $25 \mathrm{~g}$ chemical fertilizer in respect to their experimental group. Half of the chemical fertilizer was added during the planting, the other half was added two weeks after the planting. Combinations of Experimental Group are shown in Table 1.

\section{Analytical Methods}

While some of the material analyses used in the experiment were performed by a Private Laboratory and some of them were performed by Giresun University Central Research Laboratory Research and Application Center. In soil samples, the levels of $\mathrm{Mg}, \mathrm{Ca}, \mathrm{Mn}, \mathrm{Fe}, \mathrm{Co}$, $\mathrm{Cu}, \mathrm{Zn}, \mathrm{Se}, \mathrm{Cd}, \mathrm{Pb}$ were analyzed as ppm by ICP-MS and $\mathrm{C}, \mathrm{H}, \mathrm{N}$ levels were analyzed as percentage by Elemental analyzer. Organic matter in Cystoseira, compost and soil samples were analyzed by dry-ashing method as percentage, and in soil samples, Na by flame photometry, $\mathrm{K}$ by $\mathrm{K}_{2} \mathrm{O}$ (ppm) $\mathrm{p} 0,83$ and total $\mathrm{P}$ by Ascorbic Acid Method as ppm, and salt(ppt), EC $(\mu \mathrm{S} / \mathrm{cm})$ and $\mathrm{pH}$ by multiprobic measurement. In Cystoseira and compost samples, total humic+fulvic acid was analyzed by TS 5869 ISO 5073 as percentage, soluble $\mathrm{K}_{2} \mathrm{O}$, total and soluble $\mathrm{B}$ by ICP-MS as ppm, $\mathrm{CaCO}_{3}$ by Scheibler calsimetric as percentage. In soil samples, $\mathrm{P}$ was analyzed by TS 8340 (Olsen) as ppm, $\mathrm{K}_{2} \mathrm{O}$ by TS 8341 (ammonium acetate) as kg/da, moisture by TS ISO 11465 
(Gravimetric) as percentage, $\mathrm{pH}$ by TS ISO 10390, EC by TS ISO 11265 as dS/m, salt by TS 8334 as ppt, lime by TS 8335 ISO 10693 (Scheibler Calsimetric) as percentage, B by TS ISO 14870 ICP-OES (DTPA) as ppm and class structure by TS ISO 11270.

\section{Statistical Calculations}

The mean and standard error values of soil, compost and seaweed samples were calculated. Data was analyzed by one-way analysis of variance (ANOVA) (Şenocak, 1998; Özdamar, 1999). All statistical analyses were performed via "SPSS" and "Statistica" software.

\section{Results and Discussion}

Results of Analyses of Brown Seaweed, Compost and Initial Soil

In this study, physical and chemical features of compost, brown seaweed and initial soil were examined and the results are presented below in Table 2, 3. In this study, physical and chemical features of compost, brown seaweed and initial soil were examined. It was found out that salt which was normally $42.7 \mathrm{ppt}$ in seaweed, decreased to $7.79 \mathrm{ppt}$ when composted. Soil salinity has an adverse effect on plant respiration, transpiration and water intake, which results in destruction in the hormonal balance, decrease in photosynthesis and protein level, and height of the plant is reduced (Dölarslan and Gül, 2012). Its $\mathrm{pH}$ level increased to 7.8 from 7.4 when it was compost state. While Cystoseira sp. consists of $0.02 \mathrm{ppm}$ $\mathrm{P}, 2.21 \% \mathrm{~N}, 12.9 \mathrm{ppm} \mathrm{Zn}, 9.28$ ppm Se, $0.06 \mathrm{ppm} \mathrm{Cd}$ on average when it is in dry state, in compost state it includes 0.79 ppm phosphorus, $3.19 \%$ nitrogen, $23.2 \mathrm{ppm}$ zinc, $10.3 \mathrm{ppm}$ selenium, $0.17 \mathrm{ppm}$ cadmium.

\section{Results of Analysis of the Experiment Groups}

Eight combinations were created in the experiment. These combinations and the results of the soil analysis of these groups were presented in Table 4. While the most organic matter content is observed in G4 and G5 with $10 \%$, the least is observed in G1 with $8 \%$. The highest $\mathrm{pH}$ amount is observed in G5 with 7.19 and the lowest $\mathrm{pH}$ amount is observed in $\mathrm{G} 4$ with 6.49 . With the addition of chemical fertilizer, $\mathrm{pH}$ values of $\mathrm{G} 4, \mathrm{G} 7$ and $\mathrm{G} 8$ decreased and the setting became slightly acidic. While urea applied to the soils had a basic effect in the beginning, as the last effect nitric acid is formed in the soil and it has an acidic effect in the soil (Topbaş, 1987). $\mathrm{N} \%$ rate is found high in compost, namely is group G3. It is observed that there has been a decrease in the amount of salt and an increase in parameters such as $\mathrm{N}, \mathrm{P}, \mathrm{pH}$, lime and moisture, when the results of about the moss after it was composted in its natural state are examined.

The total amount of the iron in the algae used in the experiment was measured as $2458 \mathrm{ppm}$ while amount in the compost obtained from this alga is measured as 1982 ppm. The changes in the amount of Cystoseira barbata's iron existing in dry matter has been examined and the amount of iron was reported in January as 3100 ppm, in March as 2600 ppm, in May as 2880 ppm, in July as 2770 ppm, in September as $1200 \mathrm{ppm}$ and in November as 2100 ppm (Atay, 1978). Our results also show similarities with this study. $P$ value is found high in G4, chemical fertilizer; and $\mathrm{Na}$ value is high in zeolite, compost group, G5. $\mathrm{K}$ and $\mathrm{K}_{2} \mathrm{O}$ values were higher than the others in G6, zeolite+ chemical fertilizer. Potassium level was measured as $86 \mathrm{ppm}$ in zeolite. The effects of soil conditioners and organic fertilizers on the fertility of hazelnut trees were researched and the potassium amount in the soil including clinoptilolit+organic fertilizer was found as 75/94 kg/da (Özyazıcı et al., 2010). The results of that research are consistent with our study. The highest values of $\mathrm{Mn}, \mathrm{Na}, \mathrm{Ca}, \mathrm{Mg}, \mathrm{Fe}, \mathrm{Cu}$, Co elements were found high in the soil in which zeolite and chemical fertilizer were added. In a study, researchers have examined whether zeolite facilitates effectiveness of the use of water and fertilizer in spinach production and came up with positive results (Burriesci et al., 1984). In another study, researchers found positive results for the water and fertilizer economy about tomato plants grown in hydroponic environment with natural zeolite (Gonzales, 1988).

Table 1 Combinations of experimental group

\begin{tabular}{l|l}
\hline Groups & \multicolumn{1}{|c}{ Component } \\
\hline G1 & Control (soil) \\
G2 & Soil + Zeolite \\
G3 & Soil + Compost \\
G4 & Soil + Chemical fertilizer \\
G5 & Soil + Zeolite + Compost \\
G6 & Soil + Zeolite + Chemical fertilizer \\
G7 & Soil + Compost + Chemical fertilizer \\
G8 & Soil + Zeolite + Compost + Chemical fertilizer \\
\hline
\end{tabular}

Table 2 Some of the chemical and physical properties of brown seaweed and compost.

\begin{tabular}{l|cc}
\multicolumn{1}{c}{ Parameter } & Brown seaweed & Compost \\
\hline Organic matter $(\%)$ & 71 & 68 \\
$\mathrm{pH}$ & 7.40 & 7.80 \\
$\mathrm{EC}(\mathrm{dS} / \mathrm{cm})$ & 1.36 & 1.22 \\
$\mathrm{THFA}$ & 36.3 & 34.3 \\
$\mathrm{~K}_{2} \mathrm{O}(\%)$ & 3.06 & 2.57 \\
Lime $(\%)$ & 2.29 & 2.82 \\
Salt $(\mathrm{ppt})$ & 42.7 & 7.79 \\
Moisture $(\%)$ & $*$ & 14.3 \\
$\mathrm{~N}(\%)$ & 2.21 & 3.19 \\
$\mathrm{P}(\mathrm{ppm})$ & 0.02 & 0.79 \\
$\mathrm{Bor}(\mathrm{ppm})$ & 1617 & 9.62 \\
$\mathrm{Soluble} \mathrm{Boron}(\mathrm{ppm})$ & 1502 & 1.25 \\
$\mathrm{Na}(\mathrm{ppm})$ & 399 & 361 \\
$\mathrm{~K}(\mathrm{ppm})$ & 5234 & 825 \\
$\mathrm{Mg}(\mathrm{ppm})$ & 7409 & 6660 \\
$\mathrm{Ca}(\mathrm{ppm})$ & 587 & 427 \\
$\mathrm{Mn}(\mathrm{ppm})$ & 138 & 62.5 \\
$\mathrm{Fe}(\mathrm{ppm})$ & 2458 & 1982 \\
$\mathrm{Co}(\mathrm{ppm})$ & 1.57 & 1.00 \\
$\mathrm{Cu}(\mathrm{ppm})$ & 5.89 & 5.19 \\
$\mathrm{Zn}(\mathrm{ppm})$ & 12.9 & 23.2 \\
$\mathrm{Se}(\mathrm{ppm})$ & 9.28 & 10.3 \\
$\mathrm{Cd}(\mathrm{ppm})$ & 0.06 & 0.17 \\
$\mathrm{~Pb}(\mathrm{ppm})$ & 1.09 & 0.69 \\
\hline & &
\end{tabular}

*Not found; Total humic and fulvic acid (\%) 
Table 3 Some of the chemical and physical properties of first soil material (ppm).

\begin{tabular}{l|clclc}
\hline \multicolumn{1}{c|}{ Parameter } & Result & \multicolumn{1}{c}{ Parameter } & Result & Parameter & Result \\
\hline $\mathrm{pH}$ & 7.13 & Silt \% & 31.7 & $\mathrm{Mn}(\mathrm{ppm})$ & 348 \\
EC $(\mathrm{dS} / \mathrm{m})$ & 0.22 & Sand \% & 51.3 & $\mathrm{Fe}(\mathrm{ppm})$ & 14808 \\
Organic matter $(\%)$ & 10.5 & $\mathrm{P}(\mathrm{ppm})$ & 0.01 & $\mathrm{Co}(\mathrm{ppm})$ & 7.56 \\
$\mathrm{C} \%$ & 5.08 & $\mathrm{Bor}(\mathrm{ppm})$ & $<0.001$ & $\mathrm{Cu}(\mathrm{ppm})$ & 16.7 \\
$\mathrm{H} \%$ & 0.23 & $\mathrm{~K}_{2} 0(\mathrm{ppm})$ & 88 & $\mathrm{Zn}(\mathrm{ppm})$ & 25.9 \\
$\mathrm{~N} \%$ & 0.05 & $\mathrm{~K}_{2} 0(\mathrm{Kg} / \mathrm{Da})$ & 26.8 & $\mathrm{Se}(\mathrm{ppm})$ & 3.74 \\
Salt \% & 0.008 & $\mathrm{Na}(\mathrm{ppm})$ & 47 & $\mathrm{Cd}(\mathrm{ppm})$ & 0.02 \\
Lime \% & 1.24 & $\mathrm{~K}(\mathrm{ppm})$ & 4.00 & $\mathrm{~Pb}(\mathrm{ppm})$ & 4.88 \\
Texture & $\mathrm{TIN}$ & $\mathrm{Clay} \%$ & 17.0 & $\mathrm{Mg}(\mathrm{ppm})$ & 1595 \\
Moisture \% & 4.62 & $\mathrm{Ca}(\mathrm{ppm})$ & 4.03 & & \\
\hline
\end{tabular}

Table 4 Results of the analysis performed in experiment groups

\begin{tabular}{|c|c|c|c|c|c|c|c|c|}
\hline Parameters & G1 & $\mathrm{G} 2$ & G3 & G4 & G5 & G6 & G7 & G8 \\
\hline Organic Matter (\%) & 8.00 & 9.50 & 9.50 & 10.00 & 10.00 & 9.00 & 9.50 & 9.00 \\
\hline $\mathrm{C} \%$ & 5.08 & 3.83 & 4.22 & 4.01 & 3.36 & 3.33 & 4.99 & 2.23 \\
\hline $\mathrm{H} \%$ & 0.23 & 0.12 & 0.35 & 0.44 & 0.09 & 0.11 & 0.17 & 0.17 \\
\hline $\mathrm{N} \%$ & 0.05 & 0.01 & 0.09 & 0.04 & $*$ & 0.01 & 0.06 & 0.03 \\
\hline Salt $\%$ o & 0.08 & 0.07 & 0.08 & 0.06 & 0.05 & 0.10 & 0.08 & 0.09 \\
\hline Lime $\%$ & 1.24 & 1.05 & 1.34 & 1.48 & 1.29 & 1.34 & 1.43 & 1.62 \\
\hline Moisture \% & 4.62 & 4.77 & 4.67 & 5.16 & 4.64 & 4.65 & 4.65 & 4.70 \\
\hline $\mathrm{pH}$ & 7.13 & 7.09 & 7.14 & 6.49 & 7.19 & 7.05 & 6.66 & 6.92 \\
\hline $\mathrm{EC}(\mathrm{dS} / \mathrm{m})$ & 0.22 & 0.18 & 0.21 & 0.19 & 0.14 & 0.27 & 0.23 & 0.24 \\
\hline Clay \% & 17.0 & 16.33 & 18.9 & 16.9 & 17.7 & 18.9 & 18.3 & 18.3 \\
\hline Silt \% & 31.7 & 34.5 & 32.9 & 32.3 & 30.9 & 30.3 & 31.7 & 33.7 \\
\hline Sand \% & 51.3 & 49.2 & 48.0 & 50.7 & 51.3 & 50.7 & 50.0 & 48.0 \\
\hline Total P (ppm) & 0.01 & 0.02 & 0.02 & 0.07 & 0.02 & 0.04 & 0.02 & 0.25 \\
\hline Boron (ppm) & $<0.001$ & $<0.001$ & $<0.001$ & $<0.001$ & $<0.001$ & $<0.001$ & $<0.001$ & $<0.001$ \\
\hline $\mathrm{Na}(\mathrm{ppm})$ & 47 & 54 & 49 & 42 & 139 & 37 & 56 & 21 \\
\hline $\mathrm{K}(\mathrm{ppm})$ & 73.4 & 86.1 & 72.6 & 222 & 116 & 247 & 210 & 208 \\
\hline $\mathrm{K}_{2} \mathrm{O}(\mathrm{Kg} / \mathrm{Da})$ & 26.8 & 31.4 & 26.5 & 80.8 & 42.2 & 90.2 & 76.4 & 75.9 \\
\hline $\mathrm{Ca}(\mathrm{ppm})$ & 4.03 & 7.26 & 3.69 & 2.00 & 1.79 & 8.33 & 1.17 & 0.75 \\
\hline $\mathrm{Mg}(\mathrm{ppm})$ & 1595 & 1865 & 1682 & 1477 & 1582 & 1828 & 1668 & 1534 \\
\hline Mn (ppm) & 348 & 359 & 330 & 321 & 339 & 344 & 351 & 343 \\
\hline $\mathrm{Fe}(\mathrm{ppm})$ & 14808 & 15729 & 15263 & 14798 & 14827 & 16070 & 15257 & 15075 \\
\hline Co (ppm) & 7.56 & 7.90 & 7.33 & 7.19 & 7.47 & 7.91 & 7.91 & 7.50 \\
\hline $\mathrm{Cu}(\mathrm{ppm})$ & 16.7 & 17.5 & 17.3 & 16.0 & 16.7 & 17.4 & 17.1 & 16.9 \\
\hline $\mathrm{Zn}(\mathrm{ppm})$ & 25.9 & 25.7 & 26.6 & 26.9 & 25.9 & 27.6 & 26.3 & 28.0 \\
\hline $\mathrm{Se}(\mathrm{ppm})$ & 3.74 & 3.67 & 2.98 & 2.79 & 3.21 & 3.14 & 4.17 & 2.92 \\
\hline $\mathrm{Cd}(\mathrm{ppm})$ & 0.020 & 0.017 & 0.024 & 0.024 & 0.083 & 0.024 & 0.018 & 0.022 \\
\hline $\mathrm{Pb}(\mathrm{ppm})$ & 4.88 & 4.63 & 4.97 & 5.31 & 5.01 & 4.62 & 4.83 & 5.23 \\
\hline Texture & TIN & TIN & TIN & TIN & TIN & TIN & TIN & TIN \\
\hline
\end{tabular}

*Found, but under the limits, G1: Control, G2: Zeolite, G3: Compost, G4: Chemical Fertilizer, G5: Zeolite + Compost, G6: Zeolite + Chemical Fertilizer, G7: Compost + Chemical Fertilizer, G8: Compost + Zeolite + Chemical Fertilizer

Statistical Analysis of Heavy Metal Concentrations

Statistical calculations of heavy metal contents of the soil samples in different combinations were calculated according to ANOVA (Table 5). The heavy metal concentrations at the highest values for the experimentation groups were shown in the chart. The elements with the highest amount in experimental groups are: $\mathrm{Mn}$ and $\mathrm{Cu}$ in zeolite, $\mathrm{Fe}$ and Co mostly in zeolite + chemical fertilizer; $\mathrm{Zn}$ in compost + zeolite + chemical fertilizer; Se in Compost + chemical fertilizer; $\mathrm{Cd}$ in zeolite + chemical fertilizer; $\mathrm{Pb}$ in zeolite+compost. There is a statistically meaningful relationship among the ones represented with different letters from top to bottom $(\mathrm{P}<0.05)$.

When we examine statistically, it is found out that there is not an important difference among experimental groups for $\mathrm{Mn}, \mathrm{Se}, \mathrm{Cd}, \mathrm{Pb}$ and $\mathrm{Zn}$ elements. While there is not a meaningful difference among G1, G4 and G5 for Fe element, a statistically meaningful difference between $\mathrm{G} 6$ and $\mathrm{Fe}$ is defined $(\mathrm{P}<0.05)$. There is a meaningful difference between G4 and G6, G7 for $\mathrm{Cu}$ element. And for $\mathrm{Cu}$ element there is meaningful difference between $\mathrm{G} 2$ and $\mathrm{G} 4$ experimental groups $(\mathrm{P}<0.05)$. 
Table 5 Statistical calculations of heavy metal contents of the soil samples in different combinations.

\begin{tabular}{l|llllllll}
\hline & $\mathrm{Mn}$ & $\mathrm{Fe}$ & $\mathrm{Co}$ & $\mathrm{Cu}$ & $\mathrm{Zn}$ & $\mathrm{Se}$ & $\mathrm{Cd}$ & $\mathrm{Pb}$ \\
\hline $\mathrm{G} 1$ & $348^{\mathrm{a}}$ & $14808^{\mathrm{a}}$ & $7.56^{\mathrm{ab}}$ & $16.7^{\mathrm{ab}}$ & $25.9^{\mathrm{a}}$ & $3.74^{\mathrm{a}}$ & $0.02^{\mathrm{a}}$ & $4.88^{\mathrm{a}}$ \\
$\mathrm{G} 2$ & $359^{\mathrm{a}}$ & $15729^{\mathrm{ab}}$ & $7.90^{\mathrm{ab}}$ & $17.5^{\mathrm{b}}$ & $25.7^{\mathrm{a}}$ & $3.67^{\mathrm{a}}$ & $0.02^{\mathrm{a}}$ & $4.63^{\mathrm{a}}$ \\
$\mathrm{G} 3$ & $330^{\mathrm{a}}$ & $15263^{\mathrm{ab}}$ & $7.34^{\mathrm{ab}}$ & $17.3^{\mathrm{ab}}$ & $26.6^{\mathrm{a}}$ & $2.98^{\mathrm{a}}$ & $0.02^{\mathrm{a}}$ & $4.97^{\mathrm{a}}$ \\
$\mathrm{G} 4$ & $321^{\mathrm{a}}$ & $14798^{\mathrm{a}}$ & $7.19^{\mathrm{a}}$ & $16.0^{\mathrm{a}}$ & $26.6^{\mathrm{a}}$ & $2.79^{\mathrm{a}}$ & $0.02^{\mathrm{a}}$ & $5.31^{\mathrm{a}}$ \\
$\mathrm{G} 5$ & $339^{\mathrm{a}}$ & $14827^{\mathrm{a}}$ & $7.47^{\mathrm{ab}}$ & $16.7^{\mathrm{ab}}$ & $25.9^{\mathrm{a}}$ & $3.21^{\mathrm{a}}$ & $0.08^{\mathrm{a}}$ & $5.01^{\mathrm{a}}$ \\
$\mathrm{G} 6$ & $344^{\mathrm{a}}$ & $16070^{\mathrm{b}}$ & $7.91^{\mathrm{b}}$ & $17.4^{\mathrm{ab}}$ & $27.6^{\mathrm{a}}$ & $3.14^{\mathrm{a}}$ & $0.02^{\mathrm{a}}$ & $4.62^{\mathrm{a}}$ \\
$\mathrm{G} 7$ & $351^{\mathrm{a}}$ & $15257^{\mathrm{ab}}$ & $7.91^{\mathrm{b}}$ & $17.1^{\mathrm{ab}}$ & $26.3^{\mathrm{a}}$ & $4.17^{\mathrm{a}}$ & $0.02^{\mathrm{a}}$ & $4.83^{\mathrm{a}}$ \\
$\mathrm{G} 8$ & $343^{\mathrm{a}}$ & $15075^{\mathrm{ab}}$ & $7.50^{\mathrm{ab}}$ & $16.9^{\mathrm{ab}}$ & $28.0^{\mathrm{a}}$ & $2.92^{\mathrm{a}}$ & $0.02^{\mathrm{a}}$ & $5.23^{\mathrm{a}}$ \\
\hline
\end{tabular}

\section{The Yield Analysis of the Green Bean}

The green beans were harvested three times and the average yields to groups were found as following: G1: 133; G2: 273; G3:113; G4:174; G5: 250; G6:166; G7: 232; G8: $135 \mathrm{gr} / \mathrm{m}^{2}$. The highest yield was in G2 (zeolite), while the lowest yield was in G3 (compost). The amount of the harvest is also high in group G5 in which zeolite and compost added to the soil. When added chemical fertilizers, an increase in yield was observed. However when compost is used with zeolite and chemical fertilizers, it was observed that yield decreased and lowered to the same level with the G1 control group. In a previous research the effect of fresh chicken manure (TTG), mature chicken manure (OTG) and Zeolite (Z) on wheat corn yield was studied and it was found out that when zeolite was applied fertility of wheat planted after corn increased to $40,72 \%$; and when OTG and OTG+Z were applied, the fertility increased $44,07 \%$ and $57,96 \%$ respectively. Considering the average numbers obtained in different years, it can be concluded that there has been an increase in the fertility (Gümüș and Şeker, 2014).

This study reveals that usage of seaweed as organic fertilizer is sufficient for plant nutrition elements while its solid fertilizer form is richer in plant nutrition elements. However, a long time is required for the solid fertilizer form which may decrease the demand for it. One of the difficulties is that seaweed, as a raw material, does not meet the demand. Therefore attempts for seaweed cultivation should be given more importance. Moreover if conducted for an extended time period of many years, this study, which was done with different experimentation groups, might enlighten us better with respect to fertility.

\section{Acknowledgements}

Thanks to Giresun University for its financial support (Project No: FEN-BAP-A-250414-60).

\section{References}

Altuner Z. 2010. Sistematik Botanik-I, Aktif Yayınevi, İstanbul. Altan A, Altan Ö, Alçiçek A, Nalbant M, Akbaş Y. 1998. Tavukçulukta Doğal Zeolit Kullanımı II. Ege Üniversitesi Ziraat Fakültesi Dergisi, 35 (1-2-3): 17-24.

Atay D. 1978. Deniz Yosunları ve Değerlendirme Olanakları. Başbakanlık basımevi, Ankara.
Burriesci N, Valante S, Ottana R, Cimino G, and Zipelli, C. 1984. Utilization of zeolites in spinach growing Zeolites. Science Direct 4 (1): 5-8.

Çakı Z. 2009. Ege Denizi Kıyılarında Bulunan Bazı Makro Alg Türlerinin Antimikrobiyal ve Antioksidan Aktivitelerinin Saptanmas1. Celal Bayar Üniversitesi, Fen Bilimleri Enstitüsü, Doktora Tezi pp. 119, Manisa.

Davis TA, Volesky B, Mucci A. 2003. A review of the biochemistry of heavy metal biosorption by brown algae. Water Research, 37 (18): 4311-4330.

Dölarslan M, Gül E. 2012. Toprak bitki ilişkileri açısından tuzluluk. Türk Bilimsel Derlemeler Dergisi, 5 (2): 56-59.

Gonzales R, Fuentes R. 1988. Cuban experience with the use of natural zeolite subsrates in soilless culture. Proceedings of the 7th International Congress on Soilless Culture 13-21 May 1988, Flevohof, the Netherlands

Güvenç İ, Yıldırım E. 1999. Sebze Yetiştiriciliğinde Organik Artıkların Değerlendirilmesi. Türkiye 1.Ekolojik Tarım Sempozyumu Sayfa:297-300. İzmir.

Gümüş İ, Şeker C. 2014. Farklı Organik Gübrelerin Mısır-Buğday Ekim Nöbetinde Buğdayın Verimine Bakiye Etkileri. Toprak Su Dergisi 3 (1): 1-5.

Krishnani KK, Ayyappan S. 2006. Reviews of Environmental Contamination and Toxicology. Heavy Metals Remediation of Water Using Plants and Lignocellulosic Agrowastes. Springer New York. pp 59-84

Ostapczuk P, Struck BD, Pelzer R, Emons H, Mohl C. 1997. Statistical evaluation of ecosystem properties influencing the uptake of $\mathrm{As}, \mathrm{Cd}, \mathrm{Co}, \mathrm{Cu}, \mathrm{Hg}, \mathrm{Mn}, \mathrm{Ni}, \mathrm{Pb}$ and $\mathrm{Zn}$ in seaweed (Fucus vesiculosus) and common mussel (Myilus edulis).Science of the Total Environment 207, 29-42.

Özdamar K. 1999. SPSS İle Biyoistatistik. Kaan Kitapevi Yayınları pp. 454, Eskişehir.

Özyazıcı G, Özdemir O, Özyazıcı MA, Turan A, Üstün GY. 2010. Bazı Organik Materyallerin ve Toprak Düzenleyicilerin Organik Fındık Yetiştiriciliğinde Verim ve Toprak Özellikleri Üzerine Etkileri. Türkiye IV. Organik Tarım Sempozyumu, 28 Haziran1 Temmuz 2010, Erzurum. http://orgprints.org/18627.

Sivasankari S, Venkatesalu V, Anantharaj M, Chandrasekaran M. 2006. Effect of seaweed extracts on the growth and biochemical constituents of Vigna sinensis. Bioresource Technology 97 (14): 1745-1751.

Şenocak M. 1998. Biyoistatistik. İstanbul Üniversitesi Cerrahpaşa Tıp Fakültesi Yayınları pp. 314, İstanbul.

Topbaş MT. 1987. Azotlu gübreler. Selçuk Üniversitesi Yayınları, Konya.

Ülker M, Ceyhan E. 2008. Orta Anadolu Ekolojik Şartlarında Yetiştirilen Fasulye (phaseolus vulgaris 1.) genotipleri-nin bazı tarımsal özelliklerinin belirlenmesi. Selçuk Tarım Bilimleri Dergisi 22(46), 77-89. 